\title{
THE EFFECT OF THE BUSINESS ACTIVITY ON THE CONCENTRATION OF NEW CONSTRUCTION REAL ESTATE MARKETS
}

\section{Bielienkova O. Yu.}

\section{INTRODUCTION}

The real estate development is one of the key sectors of the economy of any country; it acts as a driving force at growth of economy, though along with that its response on downturn in economic activity is stronger compared to the other sectors.

In Ukraine, the construction industry is stagnant. For the fifth consecutive year, demand at the new construction real estate markets in all the regions is under pressure of adverse macroeconomic situation that has a negative effect on the volumes of housing sales and makes a fall in prices. In predicting the tendencies of the further market development, the opinions of developers have diverged in the opposite directions, namely: some analysts believe that there is to be no further decrease in the real estate prices, since the market has reached the "bottom", and some - that the price decrease is to continue $^{1}$. In order to objectively evaluate the forecasts of developers, their ability to influence the market conditions, it is necessary to analyze the level of competition in the market of new buildings and the degree of effect of individual firms on its development.

Competition is a key feature of market economy, its essential component and a prerequisite for its functioning and development. A developed competitive environment is not only the basis for the development of new opportunities to gain competitive advantages, development of strategies of individual market players, but is also the process of development of economic systems. At that, the competitive environment includes not only the direct participants of the construction market, but also all the stakeholders who, acting to meet their own needs, influence the market structure, generating supply and demand, forming expenditures of participants, etc.

At evaluation of competition in the construction markets, several approaches are used to analyze the behavior of individual companies and the

\footnotetext{
${ }^{1}$ Ukrainian developers predict increase in housing prices in $2016 / /$ [Electronic source] Access mode: http://ua.korrespondent. net/ business /realestate/3615553-ukrainskizabudovnyky-prohnozuuit-podorozhchannia -zhytla-v-2016-rotsi
} 
effectiveness of methods of state regulation of markets, based on the concept of the Harvard Business School "structure-behavior-result"2. At that the indicators for competition valuation are also divided into three groups, namely: structure indicators (market concentration coefficients, HerfindahlHirschman index, Gini index, etc.), company behavior indicators (it is most difficult to estimate those by formalized methods, assessment of the market entry and exit barriers, decisions on expansion or reduction of investments, etc. is used), performance indicators (Lerner index, prices, sales volume, financial results of companies at the market, etc).

An overview of the competitive environment of the construction markets of Ukrainian regions and the analysis of the effect of business activity on the market concentration will help to find out whether the investment activity, employment, number of economically active enterprises and other indicators affect the competition for individual markets.

Without diminishing the benefits of application of the behavioral indicators and the outcome indicators, we analyze the competition in the new construction housing market of the Kyiv city and the regions of Ukraine from the standpoint of the structural approach according to the method described in detail in ${ }^{3}$.

To the problems of the market structure analysis the works of the following scientists are devoted: A. Burian, V. Gerasimenko, O. Miniailo, Yu. Onishchenko, T. Tsyhan, V. Chirkova and others. In their research, they analyze the structural features of the markets by concentration indices representing the tendencies of development depending on changes in the number and sizes of the enterprises in the goods or services production market.

Despite the large number of scientific papers devoted to market concentration studies, insufficient attention is paid in the economic literature to the quantitative assessment of the market concentration for real estate developer enterprises operating in residential real estate markets.

Recently, attention of scientists to concentration at construction markets has increased. So, the regional peculiarities of competitive environment are examined by Pavlov K.V., Gritsenko O.S, Zapechna Yu.O., Tsifra T.Yu., Lysak I.V., Sorokina L.V. Such an analysis is traditionally carried out by means of concentration indices, and thus the problem of reviewing the most common indicators of market concentration

\footnotetext{
${ }^{2}$ Bain, J. (1954). Economies of Scale, Concentration, and the Condition of Entry in Twenty Manufacturing Industries. American Economic Review, 44(1), 15-39.

3 Bielienkova O.Yu., Tsifra T.Yu., Tsariuk T.M. Assessment of the processes of concentration and consolidation of banking capital in the CIS states and in the world. Ways of improving the efficiency of construction under conditions of formation of market relations .: Coll. scientific works. - issue.23. -2012 . - P.9 -13
} 
assessment, of identifying their shortcomings and advantages and selecting the ones most suitable for research purposes is considered to be a question of present interest.

\section{Assessment of concentration}

of the new construction housing markets in Ukrainian regions

Assessment of market concentration is carried out with the purpose of the ability of individual enterprises operating in the market to influence the market situation, for investigation of the market structure, for reveal of the largest by volumes of sales, by the work performed participants, this is the basis for tracking and analyzing their behavior, strategies, dynamics of development and more.

Indicators of concentration for developer enterprises operating at the new construction housing market reflect the number of firms and the volumes of construction and sales of residential estate compared to the market volume. With the smaller number of developers, higher is the level of concentration, greater the possible effect each individual enterprise can make on formation of housing prices.

To analyze the market concentration, following indicators have become the most widely used: the concentration index, the Herfindahl-Hirschman index, the Gini index ${ }^{4}$.

Concentration index. The small amount of input data needed and the ease of calculation have contributed to the fact that the market concentration index is nowadays the most widespread one of the indicators named above.

$$
C R_{k}=\sum_{i=1}^{k} s_{i}
$$

where $C R_{k}$ - concentration index;

$\boldsymbol{S}_{\boldsymbol{i}}$ - share of the i-th enterprise in the market;

$k$ - number of largest enterprises.

This indicator makes it possible to calculate the market concentration by volumes of work, or by the volumes of assets of the largest developers, while ignoring the results of activity of the small and medium market participants. If the value of this index is close to 100. the market is

${ }^{4}$ Grytsenko O. S. Evaluation of concentration of new construction real estate market of Donetsk region / O.S. Grytsenko, Yu.S. Zapiechna, I.V. Lysak // Control of complex system development. - 2017. - Issue. 32. - P. 110-113. 
characterized by a high degree of monopolization, and if it approaches zero, the market is evaluated as a competitive one ${ }^{5}$.

For the market analysis in practice, concentration levels of the three (five, seven) largest business entities are used. These are the so-called concentration ratios CR-3, CR-5, CR-7, depending on the number of the largest participants. The disadvantage of this indicator is the lack of accounting for all the business entities operating in the market, since for the objective analysis of the competitive environment the total number of entities on which the remaining volume of the market being analyzed rests may be relevant.

It is possible to overcome this shortcoming by means of application of the Herfindahl-Hirschman Market Concentration Index (HHI) that takes into account the total number of enterprises operating in a given market. This index is suggested for application in the market concentration analysis by the American economist and Justice Department employee William Baxter, and today it is one of the most widespread indicators used to analyze the market concentration.

The Herfindahl-Hirschman Market Concentration Index shows the share of small businesses in a given market. The HHI is calculated as the sum of the squares of shares (given in percent) of each one of the enterprises operating in the market. The value of this index is determined as the sum of market share squares in the market structure attributable to each enterprise ${ }^{6}$ :

$$
H H I=\sum_{i=1}^{n} s_{i}^{2}
$$

where $H H I$ is the Herfindahl-Hirschman index;

$\boldsymbol{s}_{\boldsymbol{i}}$ - share of the i-th enterprise in the market;

$\mathrm{n}$ - number of enterprises in the market.

The Herfindahl-Hirschman index proves the importance of the large enterprises, with assigning larger specific weight to those compared to the smaller ones, and is quite sensitive to the entrance of new businesses to the market. This index becomes less sensitive to changes with increase of the number of enterprises in the market. The index is easy to calculate because it does not depend on the market volume as a whole, but reflects the change in

\footnotetext{
5 Tsykhan T.V. Theoretical bases of control of economic concentration // www.jurenergo.kiev.ua/statti/osncontr.doc

${ }^{6}$ Chyrkov Volodymyr. Market Concentration Indicators [Electronic source] - Access mode: http://www.kmu.gov.ua/amc/control/uk/publish/article?showHidden=1\&art_id $=4940$ 8\&cat_id=47049\&ctime $=1202372165628$
} 
the market share of the smallest or the largest enterprise. This index is a function decreasing with the increase in the number of enterprises in the relevant market in the case of uneven distribution of market shares ${ }^{7}$.

The market is considered to be unconcentrated if $\mathrm{HHI}<0.1$; moderately concentrated if $\mathrm{HHI}<0.18$; and highly concentrated if $\mathrm{HHI}>0.18$.

Gini Index ${ }^{8}$

$$
\text { ДЖ }=1-\frac{A}{0,5}
$$

where ДЖ is the Gini index;

0.5 - the value of the area of the triangle bounded by the Lorenz curve with uniform distribution of particles and the axes of abscissa and ordinate.

$\mathrm{A}$ - the area bounded by the actual Lorenz curve and the axes of abscissa and ordinate.

The Gini index, compiled on the basis of the Lorenz curve, expresses the nonuniformity of distribution for any characteristic, in this case - of the market shares. The higher the Gini index is, higher is the nonuniformity of market share distribution among the market participants and, therefore, higher is the market concentration and its monopolization.

For determination of the market concentration indices, the data from the website http://zabudovnyk.com.ua/ ${ }^{9}$ which generates information about objects being built in Ukraine are used.

According to the materials of the website for the years 2018-19, the data on construction of objects for Vinnytsia, Chernihiv, Cherkasy, Volyn, Kherson, Zakarpattia, Sumy, Poltava, Mykolaiv, Ternopil, Kharkiv, Rivne, Khmelnytsky, Zhytomyr, Ivano-Frankivsk regions and Kyiv city and the developer companies involved in the construction of those objects (Table 1) are selected for analysis.

In 2019, the majority of developers and residential objects are concentrated in Kyiv city, this is consistent with statistical reports according to which more than $30 \%$ of newly built housing is located in Kyiv city. Among the analyzed regions, the least number of companies are engaged in construction in the Mykolaiv, Kherson, Sumy and Cherkasy regions.

${ }^{7}$ Gerasimenko V. Banking Capital Concentration and Methods of Assessing its Level. // Bulletin of the National Bank of Ukraine - 2007. - No. 4 - P. 28-32.

${ }^{8}$ Chyrkov Volodymyr. Market Concentration Indicators [Electronic source] - Access mode: http://www.kmu.gov.ua/amc/control/uk/ publish/ article?show Hidden=1\&art_id $=49408 \&$ cat_id $=47049 \&$ ctime $=1202372165628$

${ }^{9}$ Kyiv and Ukrainian Developers // New Buildings of Kyiv and Ukraine // [Electronic source] - Access mode: https://zabudovnyk.com.ua/uk/developers/region/all 
For estimation of the concentration levels of the markets, the concentration index, Herfindahl-Hirschman and Gini indices are chosen as being widespread and fairly simple to calculate. These indices are calculated for two arrays - the number of objects and the total area of housing for sale (Table 2-4).

Table 1

Number of the objects for sale and the developers in different regions of Ukraine

\begin{tabular}{|c|c|c|c|}
\hline No. & Region & Developer number & Object number \\
\hline 1 & Vinnytsia & 15 & 25 \\
\hline 2 & Volyn & 10 & 33 \\
\hline 3 & Zhytomyr & 13 & 15 \\
\hline 4 & Zakarpattia & 7 & 18 \\
\hline 5 & Ivano-Frankivsk & 19 & 51 \\
\hline 6 & Mykolaiv & 5 & 10 \\
\hline 7 & Poltava & 10 & 34 \\
\hline 8 & Rivne & 13 & 27 \\
\hline 9 & Sumy & 4 & 16 \\
\hline 10 & Ternopil & 10 & 40 \\
\hline 11 & Kharkiv & 12 & 48 \\
\hline 12 & Kherson & 6 & 7 \\
\hline 13 & Khmelnytsky & 14 & 44 \\
\hline 14 & Cherkasy & 4 & 8 \\
\hline 15 & Chernihiv & 8 & 38 \\
\hline 16 & Kyiv city & 90 & 423 \\
\hline
\end{tabular}

Table 2

Results of calculation of the CR-3, CR-5, CR-7 indices for the housing development markets for different regions of Ukraine

\begin{tabular}{|c|c|c|c|c|c|c|c|}
\hline \multirow{2}{*}{ No. } & \multirow{2}{*}{ Region } & \multicolumn{6}{|c|}{ Concentration index } \\
\cline { 3 - 8 } & & \multicolumn{2}{|c|}{ CR-5 } & \multicolumn{2}{c|}{ CR-7 } \\
\hline & & By objects & By area & By objects & By area & By objects & By area \\
\hline 1 & Vinnytsia & 0.4 & 0.47 & 0.56 & 0.66 & 0.68 & 0.77 \\
\hline 2 & Volyn & 0.58 & 0.66 & 0.76 & 0.85 & 0.88 & 0.93 \\
\hline 3 & Zhytomyr & 0.33 & 0.46 & 0.47 & 0.67 & 0.6 & 0.81 \\
\hline 4 & Zakarpattia & 0.67 & 0.75 & 0.89 & 0.92 & 1 & 1 \\
\hline 5 & Ivano-Frankivsk & 0.39 & 0.42 & 0.55 & 0.65 & 0.69 & 0.75 \\
\hline 6 & Mykolaiv & 0.8 & 0.63 & 1 & 1 & 1 & 1 \\
\hline 7 & Poltava & 0.74 & 0.71 & 0.85 & 0.85 & 0.91 & 0.91 \\
\hline 8 & Rivne & 0.52 & 0.68 & 0.67 & 0.88 & 0.78 & 0.94 \\
\hline 9 & Sumy & 0.84 & 0.75 & 1 & 1 & 1 & 1 \\
\hline 10 & Ternopil & 0.59 & 0.65 & 0.8 & 0.83 & 0.9 & 0.93 \\
\hline 11 & Kharkiv & 0.54 & 0.58 & 0.77 & 0.8 & 0.87 & 0.9 \\
\hline 12 & Kherson & 0.57 & 0.76 & 0.86 & 0.93 & 1 & 1 \\
\hline 13 & Khmelnytsky & 0.46 & 0.52 & 0.61 & 0.72 & 0.75 & 0.84 \\
\hline 14 & Cherkasy & 0.91 & 0.96 & 1 & 1 & 1 & 1 \\
\hline 15 & Chernihiv & 0.63 & 0.82 & 0.87 & 0.96 & 0.97 & 0.99 \\
\hline 16 & Kyiv city & 0.2 & 0.28 & 0.27 & 0.36 & 0.33 & 0.43 \\
\hline
\end{tabular}


The concentration indicators shown in the Table 2 indicate a low level of concentration of the new construction real estate market in Kyiv city and the region. This leads to the conclusion that there is competition in the housing development sector. That is, none of the developers analyzed is large enough to be able to go against the market and dictate its own pricing conditions. Under such circumstances, the market presents differentiated products, with lax control of prices largely depending on market conditions. The other regions have moderate levels of concentration.

Table 3

\section{Results of calculation of the Herfindahl-Hirschman indices for the housing development markets for different regions of Ukraine}

\begin{tabular}{|c|c|c|c|}
\hline \multirow{2}{*}{ No. } & \multirow{2}{*}{ Region } & \multicolumn{2}{|c|}{ HHI } \\
\cline { 2 - 4 } & & Number of objects & Housing area \\
\hline 1 & Vinnytsia & 0.094 & 0.1 \\
\hline 2 & Volyn & 0.146 & 0.178 \\
\hline 3 & Zhytomyr & 0.084 & 0.1 \\
\hline 4 & Zakarpattia & 0.204 & 0.242 \\
\hline 5 & Ivano-Frankivsk & 0.094 & 0.172 \\
\hline 6 & Mykolaiv & 0.32 & 0.201 \\
\hline 7 & Poltava & 0.216 & 0.21 \\
\hline 8 & Rivne & 0.127 & 0.189 \\
\hline 9 & Sumy & 0.302 & 0.221 \\
\hline 10 & Ternopil & 0.049 & 0.164 \\
\hline 11 & Kharkiv & 0.139 & 0.155 \\
\hline 12 & Kherson & 0.18 & 0.227 \\
\hline 13 & Khmelnytsky & 0.106 & 0.126 \\
\hline 14 & Cherkasy & 0.344 & 0.546 \\
\hline 15 & Chernihiv & 0.194 & 0.339 \\
\hline 16 & Kyiv city & 0.026 & 0.002 \\
\hline
\end{tabular}

The market is considered to be unconcentrated if $\mathrm{HHI}<0.1$; moderately concentrated if $\mathrm{HHI}<0.18$; and highly concentrated if $\mathrm{HHI}>0.18$.

Thus, the markets of Kyiv city, Vinnytsia and Zhytomyr regions are unconcentrated. Highly concentrated are the markets of Cherkasy, Chernihiv, Sumy, Poltava, Mykolaiv, Zakarpattia regions. Other regions of Ukraine have a moderate level of concentration. The shortcoming of the HHI indicator is that it is highly dependent on the number of firms that are present in the sample and on their size. Therefore, in the case of its application for the markets with few businesses inaccuracies are possible. As the number of firms in the sample changes, concentration indices change as well. Additional data collection should be performed to confirm the calculations. It can be so that developers in these regions do not sell real estate through the Internet in all the property units, and that's why there are so few real estate units in the databases. In the other regions, the market is 
moderately concentrated, this is most commonly found in construction markets. Perfect competition, as well as the monopoly position of one developer, is not very common.

The Gini index takes values within the range from 0 to 1 . With the higher Gini index higher is the nonuniformity of market share distribution among the sellers and, therefore, all else being equal, higher is the market concentration (Table 4).

Table 4

Results of calculation of the Gini indices for the housing development markets for different regions of Ukraine

\begin{tabular}{|c|c|c|c|}
\hline \multirow{2}{*}{ No. } & \multirow{2}{*}{ Region } & \multicolumn{2}{|c|}{ GI } \\
\cline { 2 - 4 } & & Number of objects & Housing area \\
\hline 1 & Vinnytsia & 0.4 & 0.41 \\
\hline 2 & Volyn & 0.36 & 0.46 \\
\hline 3 & Zhytomyr & 0.11 & 0.36 \\
\hline 4 & Zakarpattia & 0.33 & 0.42 \\
\hline 5 & Ivano-Frankivsk & 0.47 & 0.43 \\
\hline 6 & Mykolaiv & 0.36 & 0.04 \\
\hline 7 & Poltava & 0.5 & 0.49 \\
\hline 8 & Rivne & 0.37 & 0.6 \\
\hline 9 & Sumy & 0.38 & 0.2 \\
\hline 10 & Ternopil & 0.42 & 0.47 \\
\hline 11 & Kharkiv & 0.44 & 0.49 \\
\hline 12 & Kherson & 0.12 & 0.32 \\
\hline 13 & Khmelnytsky & 0.42 & 0.49 \\
\hline 14 & Cherkasy & 0.55 & 0.63 \\
\hline 15 & Chernihiv & 0.38 & 0.60 \\
\hline 16 & Kyiv city & 0.50 & 0.60 \\
\hline
\end{tabular}

The disadvantage of this indicator is in the fact that it measures the relative sizes of firms only. Therefore, its value is the same for ten identical firms of the market and for one hundred, although it is obvious that the degree of competition for different numbers of enterprises is different. For example, for the Kyiv city market, where about 90 enterprises operate, the Gini index is the same as for the Chernihiv region (eight enterprises). Thus, for the most comprehensive view of the structure of the market, all concentration indicators are to be considered in combination, with account of their relationship.

One of the reasons for high concentration of the new construction housing market is the presence of high administrative, economic, technical, organizational barriers for market entry, those are reflected primarily in the high level of transaction expenses, during the period of entrance to a new market and during the periods of market development and further functioning in the market as well. Those barriers impede or significantly 
complicate entrance to the market for new business enterprises. Complex procedures for land acquisition, project appraisal and approval, for obtaining permitting documentation, town-planning and environmental restrictions, energy efficiency requirements for projects, significant risks, the need for high financial expenses before construction begins, etc. are the factors that impede market entry for new developers, increase market concentration. And economic development, growth of business activity, on the contrary, lead to increased competition which reduces the market concentration. Therefore, the hypothesis of the study is the assumption that business activity has a direct impact on the market concentration.

\section{Effect of business activity on concentration of the new construction housing markets in Ukrainian regions}

The term "business activity" is for long time till now used by many scientists and operating economists to characterize economic activity at the level of an individual enterprise, industry, region, and the entire economic system of the country. At that, a number of indicators are used to evaluate business activity.

Statistical data on the volume and dynamics of production, the number of large, medium and small enterprises, the number of employed, number of employed among the able-bodied population, number of part-time workers, etc., are widely used to measure business activity at the state level.

Along with the statistical information, there are disseminated surveys of experts, managers and employees of enterprises, an example of those is the Purchasing Managers' Expectation Index (PMI) calculated by the American association ISM (Institute for Supply Management, formerly - NAPM) ${ }^{10}$. This index is one of the economic indicators that show a high enough degree of accuracy in predicting growth of inflationary pressures and changes of the economic cycle phases. High accuracy of the index has led to the fact that own PMIs or similar indices are being calculated in many countries all over the world ${ }^{11}$.

Since 2013, the State Statistics Committee collects in Ukraine the data on expectations of enterprises regarding their business activity future development prospects. The heads of enterprises are surveyed on a quarterly basis by the following groups of economic activities: industry, construction,

10 ISM. "ISM Report On Business". instituteforsupplymanagement.org. https://www.instituteforsupplymanagement.org/news/content.cfm?ItemNumber=28965\&navIte mNumber $=28882 \& S S O=1$ July2019.zip (request date: 10.04 .19 )

11 "Singapore PMI". SIPMM Academy. https://sipmm.edu.sg/about-sipmmacademy/singapore-pmi/,Caixin China General Services PMI https://www.markiteconomics.com/public , PMI - Purchasing Manager https://www.silf.se/ medlem-i-silf/pmi-inkopschefsindex/,TANKAN http://www.boj.or.jp/en/statistics/tk/index.htm/ 
retail, services and agriculture. The research methodology is aligned with the recommendations for organizing and conducting enterprise business activity surveys outlined in the Joint Harmonized EU Programme of Business and Consumer Surveys ${ }^{12}$ and the OECD handbook on business activity surveys ${ }^{13}$. The research includes the results of expectations in the following areas: changes in production volumes, in prices for products, works, services, and the number of employees. Based on these data, the economic sentiment indicator is calculated ${ }^{14}$.

To estimate the levels of business activity in the regions of Ukraine, we use the indicators that, in our opinion, can characterize the business activity of construction at the level of individual regions or areas of the country, namely: disposable income per capita, migration growth (reduction), gross regional product, average monthly salary of one full-time employee, capital investments, housing stock, number of enterprises (Table 5).

For evaluation of the market concentration, the Herfindahl-Hirschman Index (HHI) is used. Since this index is calculated for not all the regions of Ukraine, hereinafter the effect of business activity on the market structure is studied only for the Vinnytsia, Chernihiv, Cherkasy, Volyn, Kherson, Zakarpattia, Sumy, Poltava, Mykolaiv, Ternopil, Kharkiv, Rivne, Khmelnytsky, Zhytomyr, Ivano-Frankivsk regions and the Kyiv city.

To estimate the degree of influence of the above indicators on market concentration, we use the determination coefficient $\left(\mathrm{R}^{2}\right)$ calculated as a measure of the dependence of the dependent variable variation on variation of independent variables and the mean linear error $(\bar{\Delta} \mathrm{j})$. The determination coefficient indicates how much the observations obtained are reproduced by the model, based on the fraction of the total deviation of the results that can be explained by the model. The higher the value of the coefficient $R^{2}$ is, the greater is the coverage.

\footnotetext{
${ }^{12}$ The Joint Harmonised EU Programme of Business and Consumer Surveys: User Guide. Brussels: European Commission, Directorate General for Economic and Financial Affairs, 2014

${ }^{13}$ Business Tendency Surveys: A Handbook. - Paris: OECD, 2003

14 Expectations of construction enterprises regarding their business activity future development prospects http://www.ukrstat.gov.ua/operativ/operativ2019/fin/rp/bud/ bud_I_2019.pdf
} 
Indicators of business activity for the regions of Ukraine

\begin{tabular}{|c|c|c|c|c|c|c|c|c|}
\hline & \multicolumn{7}{|c|}{ Indicator } \\
\hline & & 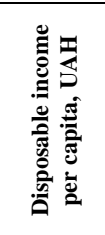 & 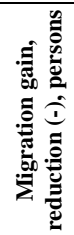 & 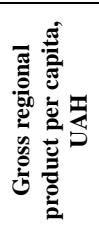 & 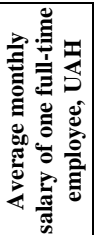 & 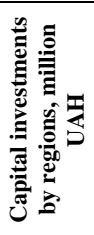 & 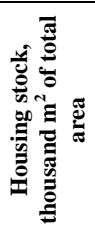 & 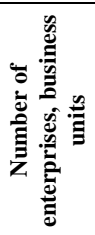 \\
\hline 1 & Vinnytsia & 54992 & -3842 & 58384 & 7801 & 17626.5 & 47621 & 9713 \\
\hline 2 & Volyn & 46475,1 & $\begin{array}{l}-687 \\
\end{array}$ & 49987 & 7324 & 8687 & 24362 & 5917 \\
\hline 3 & Dnipropetrivsk & $\begin{array}{l}72883.4 \\
\end{array}$ & 2552 & 97137 & 8862 & 60288.6 & 77297 & 29124 \\
\hline 4 & Donetsk & 31888 & -10280 & 39411 & 9686 & 26979.4 & 51539 & 9731 \\
\hline 5 & Zhytomyr & 52135.9 & -1431 & 49737 & 7372 & 8742.3 & 33791 & 6913 \\
\hline 6 & Zakarpattia & 40471.6 & 84 & 34202 & 8070 & 7500.6 & 31008 & 6425 \\
\hline 7 & Zaporizzhia & 67982.5 & -2172 & 75306 & 8726 & 15732 & 40925 & 14995 \\
\hline 8 & $\begin{array}{c}\text { Ivano- } \\
\text { Frankivsk } \\
\end{array}$ & 48367.7 & 560 & 46312 & 7551 & 9393.7 & 37027 & 8300 \\
\hline 9 & Kyiv & 63498.4 & 27142 & 90027 & 9097 & 40713.4 & 62756 & 20054 \\
\hline 10 & Kirovograd & 51018 & -2294 & 55183 & 7191 & 7181,5 & 25248 & 8068 \\
\hline 11 & Lugansk & 20618.6 & -5630 & 13883 & 7365 & 3219.3 & 18774 & 3449 \\
\hline 12 & Lviv & 55510.7 & 1886 & 58221 & 8001 & 28995.5 & 59192 & 19237 \\
\hline 13 & Mykolaiv & 55543.9 & -2213 & 60549 & 8160 & 10099.2 & 25744 & 11434 \\
\hline 14 & Odesa & 61165.6 & 7696 & 62701 & 8011 & 23787.8 & 56319 & 24707 \\
\hline 15 & Poltava & 60217.5 & 76 & 106248 & 8375 & 18636.7 & 36115 & 10959 \\
\hline 16 & Rivne & 47729.1 & -2198 & 42038 & 7469 & 7228 & 25893 & 5545 \\
\hline 17 & Sumy & 55934.4 & -2103 & 51419 & 7324 & 7749.9 & 28345 & 5949 \\
\hline 18 & Ternopil & 43512.5 & 35 & 38593 & 6969 & 8375 & 27744 & 5043 \\
\hline 19 & Kharkiv & $\begin{array}{l}60117.7 \\
\end{array}$ & 4534 & 69489 & 7657 & 23551.3 & 65116 & 23793 \\
\hline 20 & Kherson & $\begin{array}{l}50109.4 \\
\end{array}$ & -2273 & 45532 & 7058 & 8853,2 & 25039 & 8218 \\
\hline 21 & Khmelnytsky & 52487.6 & -666 & 49916 & 7346 & 11274,9 & 34896 & 7431 \\
\hline 22 & Cherkasy & 50292.6 & -2468 & 59697 & 7478 & 11110.4 & 34334 & 9176 \\
\hline 23 & Chernivtsi & 42850.4 & 222 & 31509 & 6991 & 3720.6 & 22448 & 4096 \\
\hline 24 & Chernihiv & 50895.4 & -1883 & 55198 & 6995 & 8971.3 & 29912 & 6107 \\
\hline 25 & Kyiv city & 141173.8 & 13942 & 238622 & 13542 & 200308 & 63388 & 91568 \\
\hline
\end{tabular}

The first indicator effect of which is investigated is the disposable income per capita (DIPC), million UAH ${ }^{15}$. As one can see from the Fig. 1, visually in the regions with higher income per capita there is a lower concentration of the market by the area of constructed housing (HHI), and vice versa, in the regions with lower income per capita, less housing is being built, there are fewer apartments for sale and, accordingly, concentration levels are lower. One can make an assumption that there is an inverse dependence of the HHI indicator on the DIPC characteristics (Fig. 2).

${ }^{15}$ Population income in region of Ukraine http://www.ukrstat.gov.ua/ 


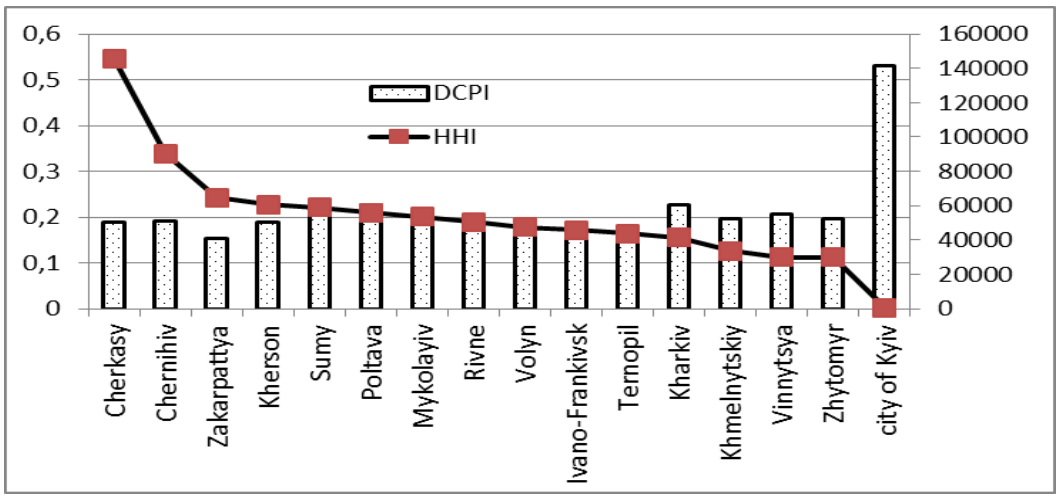

Fig. 1. The disposable income per capita (DIPC) and the Herfindahl-Hirschman indices (HHI) for different regions of Ukraine

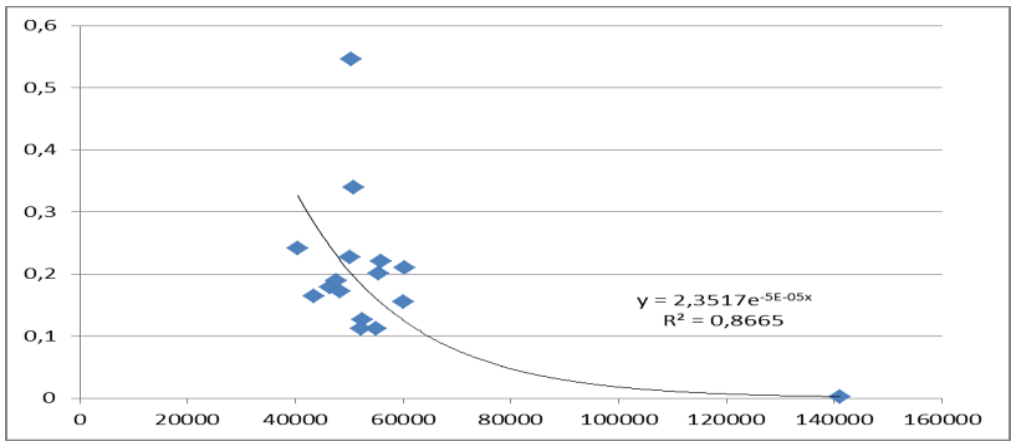

Fig 2. Effect of DIPC on the Herfindahl-Hirschman index (HHI)

The second indicator - migration growth (+), reduction (-) (Migration of population (M)), persons ${ }^{16}$. Visually it is not possible to detect the effect of this indicator on the Herfindahl-Hirschman indices (Fig. 3), the data are scattered heterogeneously. It is not possible to make unequivocally a statement about migration effect on market concentration, this is confirmed by the figures shown in Fig.4.

${ }^{16}$ Migration of population in 2018 http ://www.ukrstat.gov.ua/ 


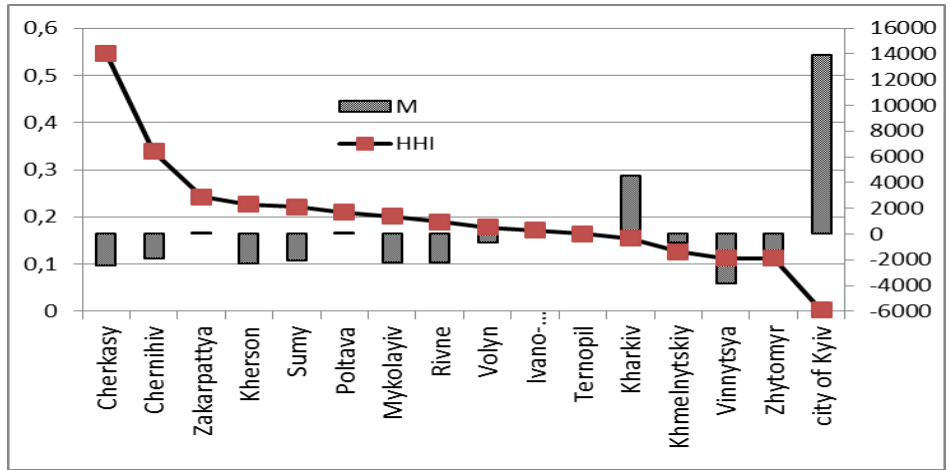

Fig. 3. Migration growth (+), reduction (-)

(Migration of population (M)) and Herfindahl-Hirschman indices (HHI) for various regions of Ukraine

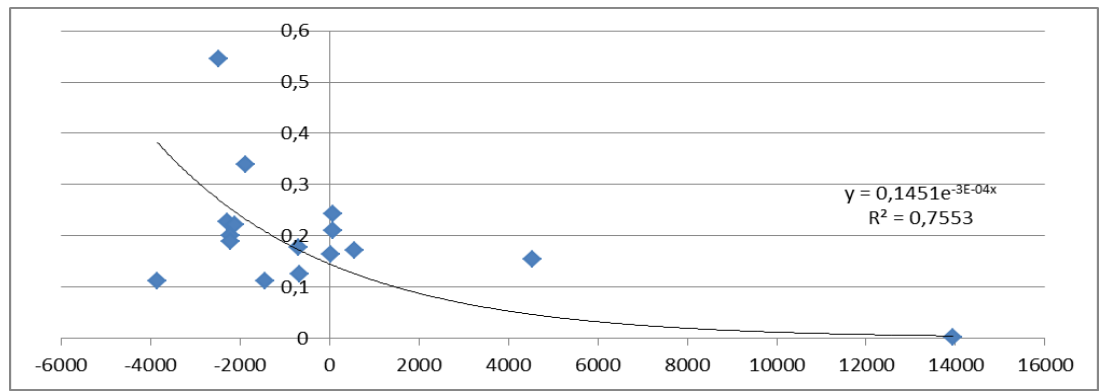

Fig. 4. Effect of migration (M) on the Herfindahl-Hirschman index (HHI)

At the national level, the most important general indicator of the country's development that characterizes the level of economic development is the gross national product (GNP), and at the regional level characterizing the level of economic development of a region, an area, it is the gross regional product (GRP). It is an indicator that measures the gross value added calculated by computing the difference between the output and the intermediate consumption for each type of economic activity, reduced by the payment for financial intermediary services. It includes all the primary income generated by production participants. Therefore, per capita gross 
regional product is chosen as the next indicator for the analysis (Per capita gross regional product (PCGRP) ${ }^{17}$, million UAH) (Fig. 5).

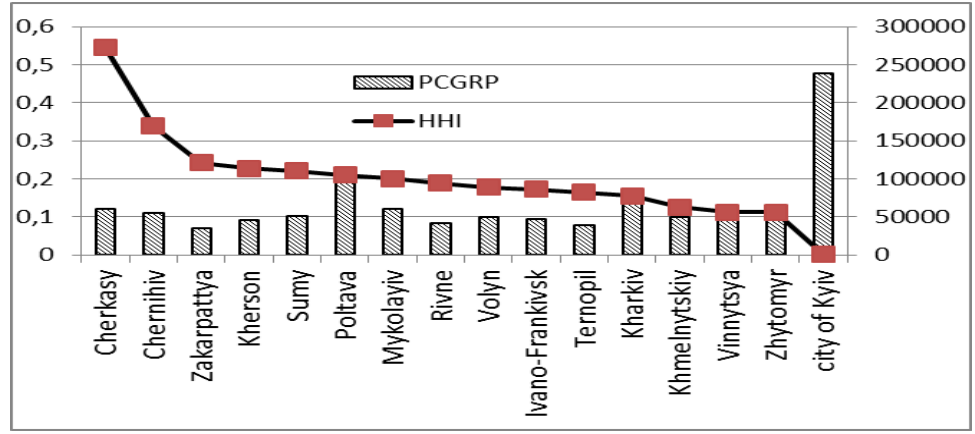

Fig. 5. Per capita gross regional product (PCGRP) and the HHI index for different regions of Ukraine

Effect of this indicator on the Herfindahl-Hirschman indices is shown in Fig. 6.

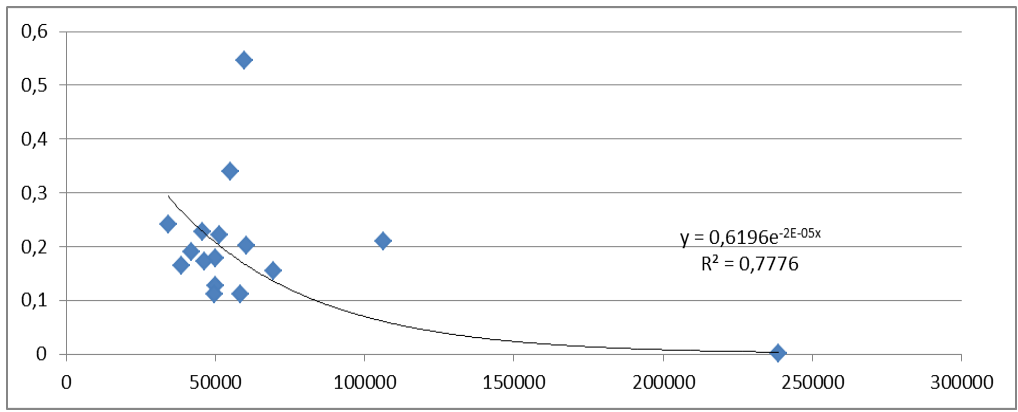

Fig. 6. Effect of PCGRP on the Herfindahl-Hirschman index (HHI)

The fourth indicator characterizing the business activity for the regions is the average monthly salary of one full-time employee (Average wages and salaries by region $(\mathrm{AW}))^{18}$, UAH. This indicator differs substantially by the regions of Ukraine, so in the Ternopil region the average monthly salary is 6969 UAH, while in Kyiv city it is almost two times larger - 13542 UAH.

${ }^{17}$ Gross regional product http://www.ukrstat.gov.ua/

${ }^{18}$ Average wages and salaries by region http://www.ukrstat.gov.ua/ 
The wages in the other regions have intermediate values, in between of these two (Fig. 7).

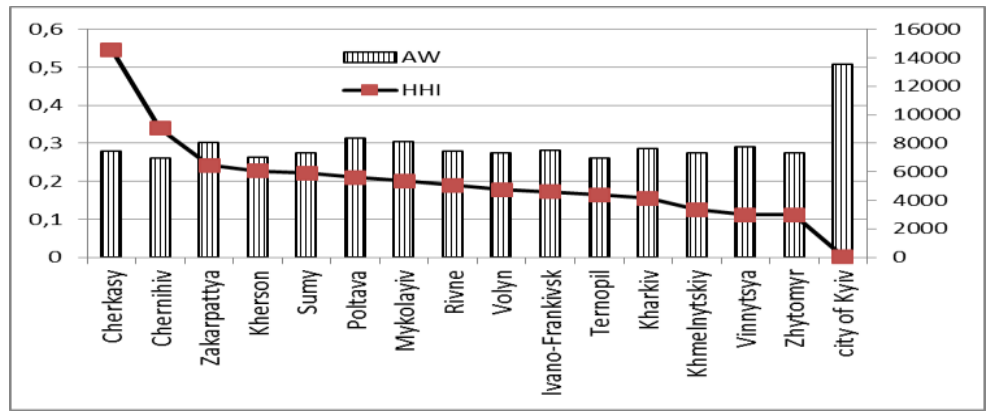

Fig. 7. The average wages and salaries by region (AW)) and the Herfindahl-Hirschman indices (HHI) for various regions of Ukraine

As one can see from Fig. 8, the degree of coverage by the model of the market concentration dependence on the level of the average monthly wages and salaries is 0.8412 , or $84.12 \%$, this is a fairly acceptable indicator.

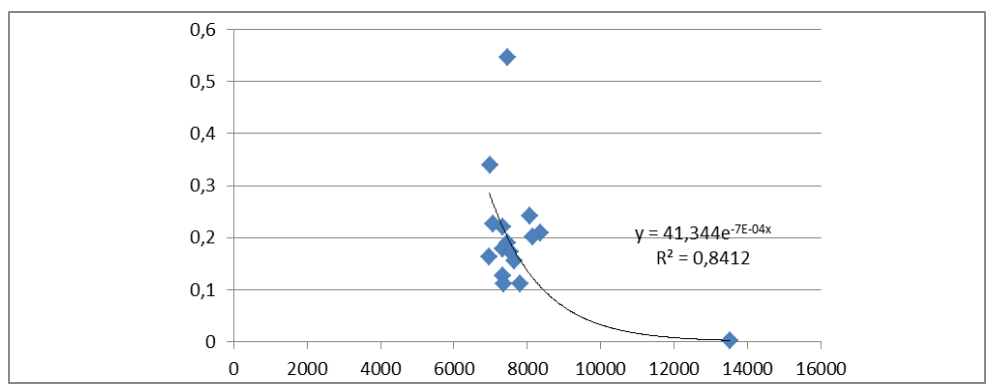

Fig. 8. Effect of average wages and salaries (AW) on the Herfindahl-Hirschman index (HHI)

The next factor characterizing the business activity in the regions of Ukraine is the indicator "capital investments by regions" (Capital investment by region) ${ }^{19}$, million UAH (Fig. 9), and it has sufficient coverage (Fig. 10).

${ }^{19}$ Capital investment by region http://www.ukrstat.gov.ua/ 


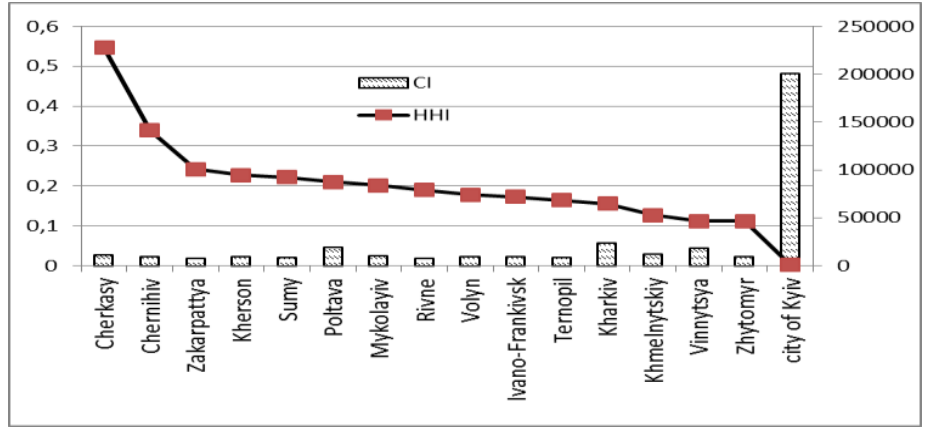

Fig. 9. Capital investments by regions

(Capital investment by region, CI) and the Herfindahl-Hirschman indices (HHI) for various regions of Ukraine

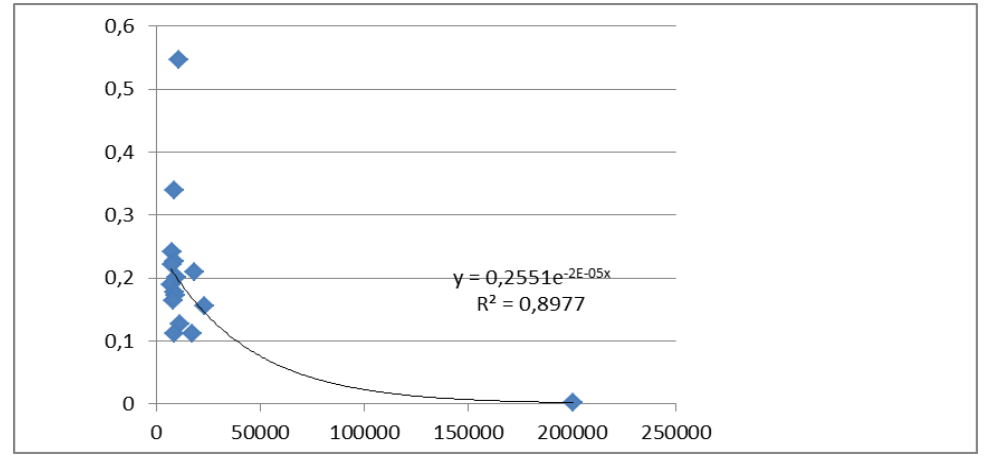

Fig. 10. The CI effect on the Herfindahl-Hirschman index (HHI)

Another indicator, not related to characteristics of business activity of an enterprise but possibly affecting the degree of concentration of new construction real estate markets, is the available total area of the housing stock in the region (indicator - housing stock (Housing stock by regions, $\mathrm{HS}^{20}$ ), thousand $\mathrm{m}^{2}$ of total area). We assume that with larger available housing stock market concentration is greater (Fig. 11).

${ }^{20}$ Housing stock by regions http://www.ukrstat.gov.ua/ 


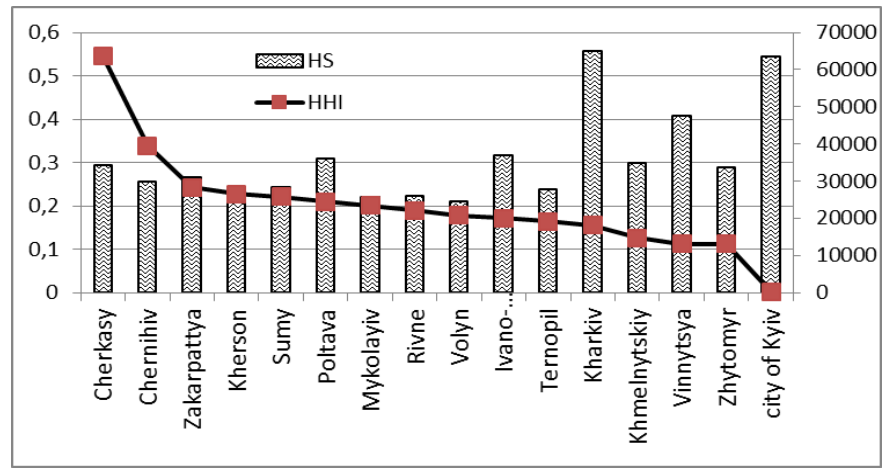

Fig. 11. Housing stock (Housing stock by regions (HS)) effect on the Herfindahl-Hirschman index (HHI)

But this hypothesis is not fortified by evidence. $\mathrm{R}^{2}$ is found to be only 0.3984 , this indicates a low degree of affecting factors coverage by the model (Fig. 12).

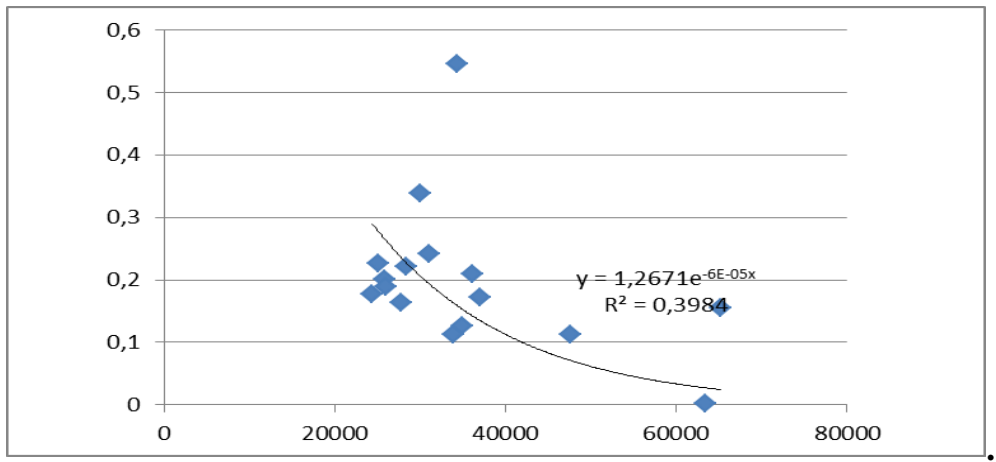

Fig. 12. Effect of HS on the HHI

The last factor for the business activity in the regions of Ukraine, the impact of which is studied in this paper, is the number of enterprises by regions (Number of enterprises by region, $\mathrm{NE})^{21}$. Visual overview of the NE and HHI graphs (Fig. 13) makes it possible to suggest that there is a dependence between these two values as well, this fact is supported by the Fig. 14.

\footnotetext{
${ }^{21}$ Number of enterprises by region http://www.ukrstat.gov.ua/
} 


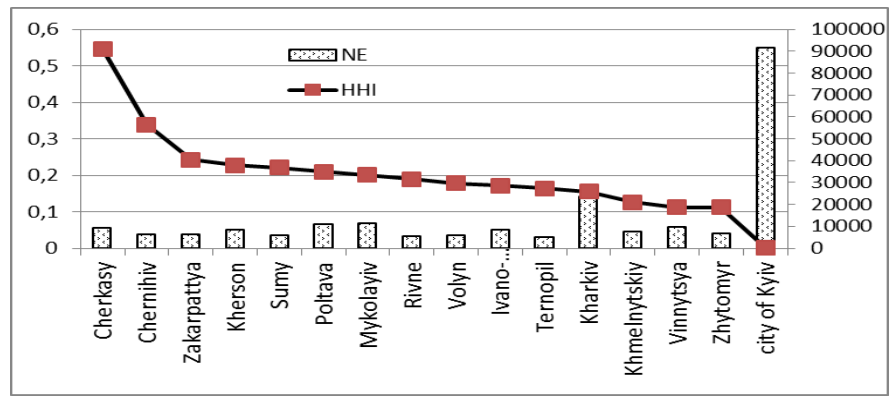

Fig. 13. The number of enterprises by regions

(Number of enterprises by region, NE) and the Herfindahl-Hirschman indices (HHI) for various regions of Ukraine)

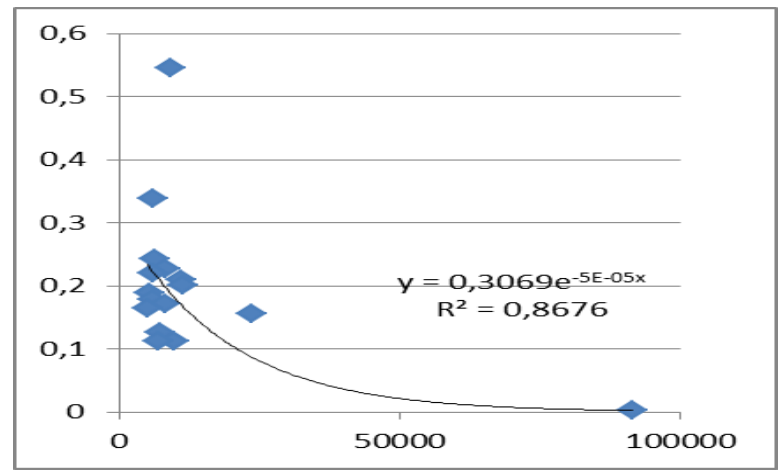

Fig. 14. Effect of the NE on the HHI

Selection of factors that have a sufficient degree of influence on the market concentration and a sufficient degree of prediction accuracy is based on the indicators $R^{2}$ and $\bar{\Delta} \mathrm{j}$ (Table 6 ). The value $\bar{\Delta} \mathrm{j}$ is the level of approximation for a particular model based on determination of its reliability by the value of the mean linear error:

$$
\begin{gathered}
\bar{\Delta}_{j}=\sum_{1}^{m} \Delta_{i} / m \\
\Delta_{i}=\left|\left(T_{i}^{\phi}-T_{i}^{p}\right) / T_{i}^{\phi}\right| \cdot 100
\end{gathered}
$$


where $\mathrm{T}^{\phi}$ - actual values of the indicator;

$\mathrm{T}^{\mathrm{p}}$ - calculated values of the indicator;

$\Delta \mathrm{i}-$ the linear error for the model by the $\mathrm{i}$-th observation $(\mathrm{i}=1,2 \ldots \mathrm{N})$.

The extent of coverage and the approximation level

Table 6

for the dependencies created

\begin{tabular}{|c|c|c|c|}
\hline No & Indicator & $\mathbf{R}^{\mathbf{2}}$ & $(\overline{\mathbf{\Delta}} \mathbf{j})$ \\
\hline 1 & Income per capita & 0.86 & 0.33 \\
\hline 2 & Migration & 0.76 & 0.54 \\
\hline 3 & GRP & 0.78 & 0.52 \\
\hline 4 & The average monthly salary of one full-time \\
employee & 0.84 & 0.46 \\
\hline 5 & Capital investments & 0.89 & 0.35 \\
\hline 6 & Total housing stock area & 0.4 & 1.18 \\
\hline 7 & Number of enterprises & 0.87 & 0.36 \\
\hline
\end{tabular}

\section{CONCLUSIONS}

According to the Table 6 it can be concluded that the market concentration of new construction real estate market is influenced by the following factors: capital investments, income per capita, number of enterprises in the region. A weak degree of coverage for the factor of the total housing stock area is found, thus this indicator has almost no effect on the new construction real estate market concentration.

However, the approximation levels of the models created are almost maximal (33\% for per capita income, $35 \%$ for capital investments, 36\% for the number of enterprises), this indicates that the accuracy of the models is not sufficiently high ${ }^{22}$. Therefore, to confirm the effect of these indicators on the market concentration additional studies should be carried out, possibly based on on the data for the regions where market concentration has not been evaluated, thus those can serve as the source of validation data.

\section{SUMMARY}

Currently, almost all the concentration indices used are fully or partially calculated and published in many countries by national statistical authorities. On the basis of those data constant monitoring of concentration processes is carried out.

In Ukraine, many of the above methods of calculation are practically not used at the state level, and calculation of specific indicators is complicated

${ }^{22}$ Economic and mathematical methods and models in construction [Text] (Ukrainian) : textbook for students of higher education institutions / V. O. Mihels [et al.] ; under the general editorship of Dr. of Sci.in economics, prof. V. O. Mikhels ; Kyiv National University of Construction and Architecture. - K. : Millenium, 2010. - 464 p. (in Ukrainian) 
by the lack of information on the construction market, this substantially distorts the real situation.

Continuous monitoring of the market situation, analysis of the level of competition, study of the trends in the development of individual markets at the level of specific regions, cities, areas, with identifying the type of competitive environment of the market shall make it possible to perform effective control of the state of competition in different regions of Ukraine, to prevent monopolization in a timely manner and to cease violations of antitrust laws.

It can be concluded that the degree of business activity in the regions of Ukraine plays a role in market concentration. Further studies should expand the range of indicators that characterize the change in business activity in specific regions, create a model that takes into account the role of those factors, etc.

Often enough at the periods of economic recovery the level of competition increases, due to high level of profitability and investment attractiveness of housing, new developers enter the market, and this reduces the level of concentration. At time of crisis the level of concentration is increasing since small companies are forced to leave the market, while large companies are forced to reduce the construction volumes. In the future studies it should be taken into account that concentration indices may vary depending on the phase of the economic cycle that characterizes the level of business activity over few, and possibly tens of years as well. Therefore, for each region the degree of new construction real estate market concentration can fluctuate depending on the phase of the economic cycle.

Monitoring of the indicators mentioned above will make it possible for the Antimonopoly Committee to develop a sound, effective antitrust policy aimed at enhancing the competitiveness in the construction industry.

\section{REFERENCES}

1. Bielienkova O.Yu., Tsifra T.Yu., Tsariuk T.M. Assessment of the processes of concentration and consolidation of banking capital in the CIS states and in the world. Ways of improving the efficiency of construction under conditions of formation of market relations .: Coll. scientific works. issue.23. - 2012. - P.9 -13

2. Gerasimenko V. Banking Capital Concentration and Methods of Assessing its Level. // Bulletin of the National Bank of Ukraine - 2007. No. 4 - P. 28-32.

3. Kyiv and Ukrainian Developers // New Buildings of Kyiv and Ukraine // [Electronic source] - Access mode: https://zabudovnyk.com.ua/ uk/developers/region/all

4. Information on housing property commissioning in Ukraine http://old.minregion.gov.ua/attachments/content-attachments/4858/.pdf 
5. Miniailo O.I., Burian A.M. The current state of competition in the new construction real estate market of Kyiv city // Business Inform. 2016. - No.4. - P. 126-130.

6. Onischenko Yu.I. Domestic banking system concentration level / [Electronic source] - Access mode: http://intkonf.org/onischenko-yui-rivenkontsentratsiyi-vitchiznyanoyi-bankivskoyi-sistemi/- Name from the screen.

7. Ukrainian developers predict increase in housing prices in 2016 // [Electronic source] - Access mode: http://ua.korrespondent. net/ business /realestate/3615553-ukrainski-zabudovnyky-prohnozuuit-podorozhchannia zhytla-v-2016-rotsi

8. Tsymbaliuk I.O. The mechanism for regulation of competitive relations in regional raw material markets: abstract. diss. Cand. of econom. Sci.: 08.00.05 / I.O. Tsymbaliuk; NAS of Ukraine. Inst-t of region. research. - L., 2008. -20 p.

9. Tsykhan T.V. Theoretical bases of control of economic concentration // www.jurenergo.kiev.ua/statti/osncontr.doc

10. Chyrkov Volodymyr. Market Concentration Indicators [Electronic source] - Access mode: http://www.kmu.gov.ua/amc/control/uk/ publish/ article? showHidden $=1 \&$ art_id $=49408 \&$ cat_id $=47049 \&$ ctime $=1202372165628$

11. Bain, J. (1951). Relation of Profit Rate to Concentration: American Manufacturing,1936- 1940. Quarterly Journal of Economics, 65(3), 293-324.

12. Bain, J. (1954). Economies of Scale, Concentration, and the Condition of Entry in Twenty Manufacturing Industries. American Economic Review, 44(1), 15-39.

13. Analytical materials on the consistency of respondents' estimates of the state of their business activities revealed by the results of the State statistical survey «State of business activity of enterprises», with intraannual statistical data http://www.ukrstat.gov.ua/operativ/operativ2015/ fin/rp/tend_act.pdf

14. Pavlov K.V., Pavlova O.M. Formation and regulation of competitive relations at regional housing markets of Ukraine: monograph. Lutsk. 2019. 542.

15. Pavlov K.V., Pavlova O.M. Regional market of real estate: conjuncture, factors of formation and influence. International Journal of New Economics, Public Administration and Law. Publisher: Cech Rzemiosł Różnych, Dr hab. 2019. 1(3).

16. Pavlov K.V. Assessment of competitiveness of the regional residential real estate markets of Ukraine: monograph. Lutsk. 2018. 482.

17. Danylina S.O. The system of indicators of concentration in economy 
http://dspace.oneu.edu.ua/jspui/bitstream/123456789/1640/1/Система\%20п оказників \%20концентрації\%20економіки.pdf

18. Kyryliuk A.O. Methods for estimating the level of economy concentration and monopolization http://www.economyandsociety.in.ua /journal/3_ukr/12.pdf

19. Bielienkova O. Yu. Evaluation of concentration of new construction real estate market of Kyiv city and Kyiv region / O. Yu. Bielienkova, T. Yu. Tsyfra, Yu. O. Zapiechna. // Actual problems of economy. - 2017. - No.6. - P. 196-203.

20. Grytsenko O. S. Evaluation of concentration of new construction real estate market of Donetsk region / O.S. Grytsenko, Yu.S. Zapiechna, I.V. Lysak // Control of complex system development. - 2017. - Issue. 32. P. 110-113.

21. Sorokina L.V. Investigation of influence of macroeconomic regulators on the dynamics of capital accumulation in the construction business of Ukraine / L.V. Sorokina // Current problems of economy. 2012. - No. 6. - P. 69-81. - Access mode: http://nbuv.gov.ua/UJRN/ ape_2012_6_10

22. An econometric toolkit for managing financial security of a construction company: [monogr.] / L.V. Sorokina, S.P. Stetsenko, A.F. Goiko, K.V. Izmailova, T.Yu. Tsyfra [et al.]; under sci. ed. of Doctor of Economics, prof. L.V. Sorokina. - K. : Kyiv National University of Construction and Architecture; Kryvyi Rih: Published SEP Cherniavskyi D.O., 2017. - P. 4-26.

23. Ryzhakova G. Implementation of principles of biospheric compatibility in the practice of ecological construction in Ukraine [Текст] / D. Chernyshev, I. Ivakhnenko, G.Ryzhakova, K.Predun // International Journal of Engineering \& Technology - UAE: Science Publishing Corporation, 2018- Vol 10. No 3.2: Special Issue 2 pp. 584-586.

24. Tetyana Marchuk, Dmytro Ryzhakov, Galyna Ryzhakova and Sergiy Stetsenko (2017). Identification of the basic elements of the innovationanalytical platform for energy efficiency in project financing. Investment Management and Financial Innovations Vol. 14(4), pp. 12-20.

\section{Information about the author: Bielienkova O. Yu.,}

$\mathrm{PhD}$ in Economics, Associate Professor, Associate Professor at the Department of Construction Economics, Kyiv National University of Construction and Architecture 31, Povitroflotsky Ave., Kyiv, 03037, Ukraine 